\title{
The Resource-Seeking Internationalization Process of a Nongovernmental Organization
}

Paula Porto ${ }^{1}$

Angela da Rocha ${ }^{2}$

${ }^{1}$ Fundação de Apoio à Escola Técnica, Rio de Janeiro, RJ, Brazil.

${ }^{2}$ Pontifícia Universidade Católica, Rio de Janeiro, RJ, Brazil.

Received 20 November 2019. This paper was with the authors for two revisions. Accepted 18 April 2021. First published online 28 May 2021.

Editor-in-chief: Carlo Gabriel Porto Bellini (Universidade Federal da Paraíba, João Pessoa, PB, Brazil)

Associate editor: Bent Petersen (Copenhagen Business School, Denmark), Mohamed Amal (Universidade Regional de Blumenau, Brazil)

Reviewers: Two anonymous reviewers

Editorial assistants: Kler Godoy and Simone Rafael (ANPAD, Maringá, PR, Brazil 


\section{ABSTRACT}

This paper aims at investigating the resource-seeking internationalization process of an international nongovernmental organization (INGO) from the process point of view. INGOs have received scant attention in the international business literature, despite their relevance in almost every aspect of aid and development and as actors of global governance. The research question addresses the issue of whether or not INGOs can follow a path similar to business firms in their internationalization process. The study departs from two different theoretical perspectives - the Uppsala model and the born global perspective - to study the case of the NGO Médecins Sans Frontières (Doctors Without Borders), an international, private, nonprofit, member-based organization. We identify three stages in the resource-seeking internationalization process of the NGO, which present similarities with that of business organizations. The study contributes to the IB literature by revealing key aspects of the internationalization trajectory of an NGO to raise funds and recruit volunteers in advanced and emerging economies with the purpose of employing these resources to support its emergency assistance activities in less developed countries, and to the literature on INGOs in exploring the issue of resource-seeking internationalization.

Keywords: NGO; internationalization process; resource seeking

JEL Code: M16, L31. 


\section{INTRODUCTION}

Nongovernmental organizations (NGOs) have become an important part of the global landscape (Dichter, 1999). The number of international NGOs has grown substantially over the past century, especially since the 1970s. According to the NGO Branch of the United Nations (United Nations, 2017), there are more than 30,000 international NGOs worldwide that are affiliated with the United Nations Economic and Social Council, with international activities that focus on economic and social development, conflict resolution, peacemaking, and humanitarian assistance. As a result, scholars from a variety of disciplines, including economics, international relations, development studies, political science, and sociology, among others, have used different lenses to examine the NGO phenomenon.

NGOs are, however, difficult to define and to classify (Dichter, 1999; Martens, 2002; Parker, 2003). Authors debate whether or not they are part of the third sector, with some arguing that they are similar to business organizations (Kistruck, Qureshi, \& Beamish, 2013), except that they are not-for-profit entities (Bebbington, Hickey, \& Mitlin, 2008; Uphoff, 1996), and thus should be considered as part of the private nonprofit sector (Salomon \& Anheier, 1997). In fact, NGOs serve beneficiaries, while business organizations serve customers. In addition, NGOs are accountable to various stakeholders, such as donors and contributors, beneficiaries, employees, public officials, and government agencies, while business organizations are accountable to shareholders, customers, employees, suppliers, government, and society in general. Other scholars have debated whether organizations that get most of their funding from governments should even be called nongovernmental (Smillie, 1998). After a detailed review of the meanings associated with the term, Martens (2002) defines NGOs as "formal (professionalized) independent societal organizations whose primary aim is to promote common goals at the national or the international level" (Martens, 2002, p. 282).

Part of the reason for this debate comes from the wide variety of institutional types and the "multidimensional nature of NGOs," thus making the classifying of NGOs "a perplexing dilemma" (Vakil, 1997, p. 2057). Vakil offers several different dimensions to be considered when classifying an NGO. McGaughey (2018), in turn, looks specifically at NGOs involved with human rights and proposes six different types. In light of the large number of taxonomies emanating from different disciplines and theoretical perspectives, a simple but useful classification is offered by Kellow and Murphy-Gregory (2018), who distinguish between operational NGOs, which are "involved in the delivery of programs," and advocacy NGOs, "involved in advocacy or campaigning" (Kellow \& Murphy-Gregory, 2018, p. 7). Nevertheless, despite the differences, there is a consensus that these organizations do have characteristics in common and are thus definable.

Many NGOs have spread their activities to several countries and become global. A number of factors seem to be behind the rise of international NGOs (INGOs) - also called global or transnational NGOs - such as increased global connectedness, technological advances, and social changes (Anheier \& Themudo, 2005), and they seem to be significantly motivated by fundraising pressures (Aldashev \& Verdier, 2009; Kistruck et al., 2013). Smillie (1998) praised their "capacities and efficiencies" (Smillie, 1998, p. 185) to provide faster responses to international 
problems than national governments are capable of, and he also lauded their ability to secure political support.

Despite the importance of INGOs in almost every aspect of aid and development and as actors of global governance, and despite the interest in these organizations by scholars from diverse fields and theoretical perspectives, scant attention has been given to the subject in the area of international business (IB), especially when it comes to studying these organizations as actors per se, or, as Lambell et al. (2008) put it, "in their own right" (Lambell, Namia, Nyland, \& Michelotti, 2008, p. 85). In fact, the IB literature is largely silent when it comes to examining the internationalization of other types of organizations besides multinational enterprises (MNEs). Buckley, Doh, and Benischke (2002) pioneered the call for IB scholars to look specifically at the international activities of NGOs as "candidates for important research agendas" (Buckley, Doh, $\&$ Benischke, 2002, p. 369). Buckley's quest was supported by Teegeen, Doh, and Vachani (2004), who also called for broadening the scope of IB research "to include non-state, non-firm actors" (Teegeen, Doh, \& Vachani,2004, p. 464). Specifically, these authors suggested that the internationalization process of NGOs needed to be addressed by the IB field: "NGOs might internationalize in stages ... and follow a life cycle ... International NGOs' modes of entry into foreign markets may be predicted by experience and cultural similarity, as we have seen for their MNE counterparts" (Teegen et al., 2004, p. 676).

Lambell et al. (2008) evaluated the progress of IB research on NGOs and realized that the issues raised by Teegen et al. (2004) had not yet been sufficiently addressed, excepting the study of strategic alliances between MNEs and NGOs. Kourula and Laasonen's (2010) review of the literatures on business and society, management, and IB confirmed this state of affairs. More recent studies that examine the international aspects of $\mathrm{NGO}$ activity have also focused on the relationship between MNEs and NGOs (e.g., Bhanji \& Oxley, 2013; Nebus \& Rufin, 2010; Rana \& Elo, 2017). Accordingly, a recent literature review (Sinkovics, Sinkovics, \& ArchieAcheampong, 2019) on social responsibility issues in IB identifies the study of NGOs among the under-represented topics, which still focuses mainly on MNE-NGO interactions. In a fresh evaluation of the presence of NGOs in the IB literature, Buckley et al. (2017) acknowledge that despite IB scholars' increased interest in MNE-NGO interactions, they have remained "almost exclusively focused on understanding the MNE's resources, strategies, tactics, and responses, and rarely consider those same characteristics for its organizational counterpart [the NGO]" (Buckley et al., 2017, p. 1050). Thus, some of the issues raised by Teegen et al. (2004) remain uncovered by IB research, particularly the internationalization process of NGOs, that is, how NGOs develop and structure their international activities.

Therefore, the subject matter of the present study is the process involved in the internationalization of an NGO, seeking to contribute to filling a gap in the IB literature. The study sought to answer the following question: "To what extent does the internationalization process of NGOs follows a path similar to the internationalization process of business organizations?" Considering the similarities between INGOs and business-like organizations, it seems a logical research endeavor to investigate whether or not these organizations follow paths similar to business firms in their internationalization processes. Accordingly, we adopt two IB 
theoretical perspectives - the Uppsala model and the born global (BG) perspective - to analyze the phenomenon of NGO internationalization. Scholars (e.g. Knight \& Liesch, 2016; Welch \& Paavilainen-Mantymaki, 2014) have recommended the use of a process approach to study the internationalization of business organizations, since a dynamic approach is fundamental for understanding the phenomenon. Due to its longitudinal nature, the process approach allows for a detailed evaluation of the sequence of events in the internationalization process (Hewerdine $\&$ Welch, 2013). We argue that the process approach is also valuable to examining the internationalization of NGOs. Both theoretical perspectives selected for the study look at the process of internationalization, while other dominant theoretical perspectives in the IB field do not (e.g., internalization theory and the eclectic paradigm of international production). The Uppsala model describes a gradual internationalization path, based on the study of traditional MNEs, while the BG perspective focuses mainly on the first steps of internationalization at the very inception of a firm. However, even if the two perspectives adopt quite different understanding of the initiation of internationalization, they can be reconciled in the later steps of the process.

The method elected was the case study. Due to its longitudinal nature, the method allows for a detailed evaluation of the sequence of events in the internationalization process (Hewerdine $\&$ Welch, 2013). We chose the NGO Médecins Sans Frontières (or Doctors Without Borders) for our single case analysis. Following Kellow and Murphy-Gregory's (2018) classification, MSF is an operational NGO that operates globally to deliver emergency health services, mobilizing volunteers, donors, and material resources to accomplish its mission. The MSF case fulfills all the conditions for a single case choice: it is a special case that is revealing and suitable for the desired theoretical-empirical development (Ghauri, 2004; Pauwels \& Matthyssens, 2004). Moreover, one major reason for the choice is that there is a wealth of data available on this NGO - particularly on the process by which the organization expanded its international reach to several countries including interviews with several of its leaders in different moments of time. In addition, MSF is international since inception, thus recommending the use of both theoretical perspectives selected for the study.

It should be noted that we initially also intended to examine MSF's international expansion to serve humanitarian purposes and its entry into countries experiencing emergencies. However, as we moved ahead in the study, it became clear that there were two different processes that had to be analyzed separately. The first one is a resource-seeking internationalization process, whose main purpose is to access donation funds and recruit volunteers in more advanced countries and leading emerging economies and is characterized by the choice of potential markets and the establishment of affiliates. The second is a mission-supportive internationalization process, whose aim is to serve the INGO's humanitarian goals. In this latter process, MSF does not choose the geographic areas where humanitarian projects occur, but rather its choice is determined by the place where its services are urgently needed. Considering that these locations can vary substantially in time, although they tend to be in less developed countries, large, permanent facilities such as affiliates usually are not established in the country served by emergency projects, but mainly satellite facilities to support operational needs such as logistics and medical supplies.

Nevertheless, we concur with Edwards (2008) that, due to their diversity, one should be careful not to generalize when it comes to studying NGOs. We realize that a single case study cannot 
portray a group of organizations as diverse as NGOs, even large international NGOs. In spite of that fact, however, we believe that a detailed analysis of the internationalization of MSF to secure funds to support its emergency projects may shed some light on the dynamics of the internationalization of operational NGOs that have achieved a global scope of operations.

\section{THE INTERNATIONAL NGO}

Anheier and Themudo (2005) conceptualize INGOs as "nonprofit organizations that make significant operating expenditures across national borders and do not identify themselves as domestic actors" (Anheier \& Themudo, 2005, p. 103), while Davies (2018) defines them as "nonstate, non-profit organizations operating across three or more countries in a wide range of issue areas ..." (Davies, 2018, p. 15).

These organizations are to a degree comparable to MNEs, with activities in several countries (e.g., Dichter, 1999; Smillie, 1998; Uphoff, 1996). Like MNEs, they depend on a bureaucratic structure for their worldwide operations. Miller (2007) claimed that the organizational structure of NGOs is "a curious blend of the corporate model and political parties" (Miller, 2007, p. 353), and points out that on one hand, they have a professional staff, a management team, and a board of directors, whereas, on the other hand, they rely on contributions and other forms of funding. Meyer and Simsa (2014) go further, advocating that the adoption of business-like methods and organizational forms responds to a need to improve efficiency and effectiveness and to gain legitimacy. In their opinion, such change has brought more managerial competence and improved organizational forms to the nonprofit sector. From a political science perspective, Risse (2007) suggests that INGOs, similar to MNEs, have their governance structure shaped by the institutional environment of their headquarters' home country, but they must also abide by the regulatory environment of the countries where they operate. Thus, to respond to these environmental characteristics, INGOs have increased their bureaucratization, and have "changed their character from transnational social movements to professional organizations employing a large staff of lawyers, media experts, and country specialists” (Risse, 1997, p. 262).

The international growth of INGOs has not been achieved without facing several challenges. Kistruck, Qureshi, and Beamish (2013) have found a U-shaped relationship between geographic diversification and efficiency. In addition, increased problems of coordination are associated with international expansion (Aldashev \& Verdier, 2009). International NGOs may opt for quite different degrees of centralization/decentralization, giving more or less autonomy to their affiliates. Decentralized structures tend to invite more conflict than centralized ones. These issues have to be confronted as these organizations face growing pressures involving accountability, efficiency, and effectiveness (Lewis, 2005; Meyer \& Simsa, 2014; Werker \& Ahmed, 2008). Ebrahim (2003) notes that NGOs have performed better in relation to functional than strategic accountability, and Banks, Hulme, and Edwards (2015) evaluate NGO's social impact as weak. In addition, competition for funds among NGOs and other nonprofit organizations and social movements is ever more intense (Aldashev \& Verdier, 2009; Kistruck et al., 2013; Oelberger, Lecy, \& Shachter, 2020). 
Another crucial issue for INGOs is fundraising. In fact, scholars have warned about the difficulties involved in balancing the NGO's mission and the need to raise funds (e.g., Meyer \& Simsa, 2014), and to conciliate donors' interests and NGOs' responsibilities. These tensions are inherent to the existence of INGOs, however. In the field of economics, Aldashev and Verdier (2009) examined the implications of NGOs' international expansion in terms of fundraising using data from large international NGOs' market entries. They conclude that the increase in economies of scale associated with fundraising is behind the global expansion of large NGOs and their choice of foreign countries. Kistruck, Qureshi, and Beamish (2013) suggest that NGOs (specifically charities) internationalize due to the availability of a large donor base that is motivated to contribute to growing social demands. As a result of their ability to mobilize and commit the public to the causes they serve, INGOs seem more capable of attracting private donations than other NGOs do (Anheier \&Themudo, 2005). There is also some evidence that international donors would rather contribute to INGOs than to their domestic counterparts. This can be interpreted as a donor's risk-reduction strategy, owing to the "geographic, cultural and linguistic differences" between donors and local NGOs established in less developed countries (Oelberger et al., 2020, p. 16). It thus seems that the international growth of NGOs has been fueled by the challenges of fundraising and the need to compete for private donations.

\section{THE INTERNATIONALIZATION PROCESS}

Teegen et al. (2004), in their quest to include NGOs in the IB agenda, suggested using gradual internationalization models to understand how these organizations develop their global operations. Following their advice, but recognizing that many NGOs are international from inception (for instance, the case selected for the study, MSF), we used both the Uppsala model and the BG perspective to examine the phenomenon of NGO internationalization.

The Uppsala model (Johanson \& Vahlne, 1977) is a dynamic, path-dependent procedural model, in which events are not planned or follow a predetermined sequence (Welch, Nummela, \& Liesch, 2016). The model is dynamic in that it explains the basic internationalization mechanisms that enable the organization to continue along its international trajectory. It is path-dependent in that decisions are shaped by the company's history and its previous activities, which limit the alternatives to be followed in subsequent steps. The model seeks to systematize and explain the dynamics that accompany the internationalization process. Internationalization begins passively, usually through fortuitous contacts from abroad, which are capable of arousing management's attention about the potential of foreign countries. Companies only initiate international activities at more advanced stages of their existence. Internationalization is the result of the combination of incremental decisions that become tangible through an 'establishment chain,' characterized by the successive choice of more highly committed modes of entry into markets of increasing psychic distance. Decision-makers face uncertainty due to lack of market knowledge and they are risk averse (Björkman \& Forsgren, 1997). Psychic distance, that is, the perception of geographic, economic, cultural, and business differences between the organization's country of origin and the foreign country, affects the decision-making process; countries closer in these terms are selected earlier. The 1977 Uppsala model "has gained strong support in studies of a wide spectrum of countries and situations" (Johanson \& Vahlne, 1990, p. 14), although it has also been questioned. Criticisms relate to a lack of empirical support along the establishment chain (Ninan $\&$ Puck, 2010), a limited view of how companies acquire experiential knowledge (Forsgren, 
2002), a non-inclusion of networks (Johanson \& Vahlne, 2009), and an excessive emphasis on a linear view of the process (Vissak \& Francioni, 2013).

As a result of these criticisms and of the changing context of globalization, the model underwent a series of adjustments. The revisited Uppsala model (Johanson \& Vahlne, 2009) now rests on the concept of networks. Internationalization is conceived as the development of ties between actors in different foreign countries. As relationships evolve, organizations develop privileged knowledge about their network partners, enabling them to adapt their routines to their partners' needs. Thus, the incorporation of the network aspect required significant changes to the model regarding the concepts of learning, trust, commitment, and opportunity recognition (Johanson \& Vahlne, 2009). For Welch, Nummela, and Liesch (2016), the relationship between the model's variables changed in three important ways. First, in the context of the network, the relationship between learning and commitment went from unilateral to multilateral, that is, it now includes several partners that learn from each other and share their knowledge. Second, while experiential knowledge remained a central element, other types of knowledge were added, such as imitative learning and network-based learning. Third, learning became a trigger for the development of opportunities, and not only a mechanism to reduce uncertainty.

In addition, the 2009 Uppsala model does not focus anymore on liabilities of foreignness, as implicit in the original 1977 model, but on liabilities of outsidership. The construct of liabilities of foreignness refers to the additional costs incurred by a firm to operate in a foreign market due to its lack of familiarity with the foreign market. The concept was originally introduced by Zaheer (1995), and since then it has been frequently used in IB research (Denk, Kaufmann, \& Roesch, 2012). Liabilities of outsidership refer to the lack of a relevant position in established networks abroad. This situation is aggravated because "foreignness presumably complicates the process of becoming an insider" (Johanson \& Vahlne, 2009, p. 1415).

The BG perspective has been positioned against the Uppsala model. A parallel and broader development in the IB field, the international entrepreneurship perspective, which studies the $\mathrm{BG}$ and similar phenomena from the perspective of the entrepreneur, adopted the same position. Although both perspectives have the same object of study, the early internationalizing firm, we chose the BG perspective because it focuses on market expansion and sales, and is thus a better fit for the phenomenon of NGOs going global to reach new donors and recruit volunteers. BG companies are defined as "companies that, from or near founding, obtain a substantial portion of total revenue from sales in international markets" (Knight \& Cavusgil, 2005, p. 16). The internationalization process of these companies differs in many aspects (speed of internationalization, mode of entry, scope of activities, geographical scope, and motivations to internationalize) from MNEs and traditionally internationalizing firms, which usually expand gradually to international markets.

The time dimension is the most relevant aspect that distinguishes the internationalization process of BGs. In general, the BG trajectory is seen as a nonlinear process with interruptions and leaps. Hewerdine and Welch (2013) described the embryonic phase of a BG as a process comprised of a set of gestations of variable duration. Frequently, the initial trigger is the emergence of an 
opportunity. In the initial period, internationalization may be discontinued in order to solve problems faced by the new organization. Internationalization finally occurs when the BG enters overseas markets in search of sales or technology partnerships. In turn, Hagen and Zucchella (2014) focus on the capabilities of the founders, whom they see as the basis for beginning the internationalization process. To pursue growth in the long run, however, the organization has to develop new opportunities and pursue learning, which can be accomplished by developing ties and entering foreign networks. It is not the quantity, but the quality of the relationships that promotes the exchange of knowledge and contributes to the legitimacy of the organization in the foreign country. Jones and Coviello (2005) suggest that changes in the environment lead to the choice of entry mode into a foreign market. The choice of entry mode causes a cyclical process that is moderated by experiential knowledge and organizational learning. Due to the intensity of resource commitment, the chosen mode of entry may involve more risks and may occur in countries more culturally distant from the firm's home country. Changes in strategic direction are responses to alterations in the environment, fortuitous and revolutionary events that can redirect organizational development. Gabrielsson, Kirpalani, Dimitratos, Solberg, and Zucchella (2008) propose a framework with three phases to describe BG internationalization after inception. In the introductory phase, the BG has little organizational structure and limited resources (mainly human capital). The BG needs both tangible and intangible assets in order to go international. In the second phase - growth and resource accumulation -, the BG learns from its partners as it develops its international potential. In the third and final phase, the BG adopts a strategy to break from the network in order to launch its own products and services and gain a stronger position in the foreign market. The entrepreneur's international orientation acts as a trigger for internationalization. While international commitment follows learning in the Uppsala model, it precedes learning in the case of BGs. Finally, BGs are faced with liabilities of newness, that is, additional costs due to their infancy (Yang \& Gabrielsson, 2018).

Table 1 summarizes the categories extracted from the literature regarding the Uppsala model (original and revisited) and the BG perspective concerning the most important characteristics of the internationalization process.

Table 1

Categories extracted from the literature

\begin{tabular}{|c|c|c|c|}
\hline Category & $\begin{array}{c}\text { Original Uppsala Model } \\
\text { (Johanson \& Vahlne, } \\
\text { 1977) }\end{array}$ & $\begin{array}{l}\text { Revisited Uppsala Model } \\
\text { (Johanson \& Vahlne, 2009) }\end{array}$ & $\begin{array}{l}\text { Born Global } \\
\text { Perspective }\end{array}$ \\
\hline $\begin{array}{l}\text { Locus of the } \\
\text { decision }\end{array}$ & Market & Network & Market and/or network \\
\hline Trigger(s) & $\begin{array}{l}\text { Generally passive; typically, } \\
\text { unexpected requests from } \\
\text { abroad }\end{array}$ & $\begin{array}{l}\text { Proactive or passive; } \\
\text { insertion into the network } \\
\text { generates opportunities }\end{array}$ & $\begin{array}{l}\text { Frequently proactive; orientation and } \\
\text { capabilities of the entrepreneur } \\
\text { (Hagen \& Zucchella, 2014); } \\
\text { opportunity generated by the network } \\
\text { (Gabrielsson et al., 2008; Hewerdine \& } \\
\text { Welch, 2013) }\end{array}$ \\
\hline Uncertainty & Ignorance about the market & $\begin{array}{l}\text { Ignorance about the market } \\
\text { and the network }\end{array}$ & $\begin{array}{l}\text { Less relevant; may be compensated } \\
\text { for belonging to the network }\end{array}$ \\
\hline $\begin{array}{l}\text { Risk profile of } \\
\text { decision-maker }\end{array}$ & Risk averse & Risk averse & $\begin{array}{l}\text { Risk neutral (or risk willing) (Jones \& } \\
\text { Coviello, 2005) }\end{array}$ \\
\hline Learning & $\begin{array}{l}\text { Objective and experiential } \\
\text { (most important) }\end{array}$ & Experiential and collective & $\begin{array}{l}\text { Experiential and collective (Hagen \& } \\
\text { Zucchella, 2014; Jones \& Coviello, } \\
\text { 2005) }\end{array}$ \\
\hline
\end{tabular}


Table 1 (continued)

\begin{tabular}{|c|c|c|c|}
\hline Category & $\begin{array}{c}\text { Original Uppsala Model } \\
\text { (Johanson \& Vahlne, } \\
\text { 1977) }\end{array}$ & $\begin{array}{l}\text { Revisited Uppsala Model } \\
\text { (Johanson \& VahIne, 2009) }\end{array}$ & $\begin{array}{l}\text { Born Global } \\
\text { Perspective }\end{array}$ \\
\hline Commitment & $\begin{array}{l}\text { To the market; investment of } \\
\text { resources }\end{array}$ & $\begin{array}{l}\text { To the network; investment in } \\
\text { the network }\end{array}$ & $\begin{array}{l}\text { To the business; occurs due to } \\
\text { expectations that the business will } \\
\text { succeed (Gabrielsson et al., 2008) }\end{array}$ \\
\hline $\begin{array}{l}\text { Psychic } \\
\text { distance from } \\
\text { the market }\end{array}$ & $\begin{array}{l}\text { Decision-maker's perception } \\
\text { of geographic, economic, } \\
\text { cultural, and business } \\
\text { differences between } \\
\text { domestic and international } \\
\text { markets }\end{array}$ & $\begin{array}{l}\text { Irrelevant; choice of markets } \\
\text { is dictated by the network }\end{array}$ & Irrelevant \\
\hline $\begin{array}{l}\text { Establishment } \\
\text { chain }\end{array}$ & $\begin{array}{l}\text { Evolution of international } \\
\text { activities from close to } \\
\text { distant markets and entry } \\
\text { modes of lesser to greater } \\
\text { commitment }\end{array}$ & Irrelevant & $\begin{array}{l}\text { Irrelevant; diversity of entry modes } \\
\text { and markets }\end{array}$ \\
\hline Trust & Irrelevant & $\begin{array}{l}\text { Basis for cooperation and } \\
\text { building relationships within } \\
\text { the network }\end{array}$ & $\begin{array}{l}\text { Important for obtaining the advantages } \\
\text { of belonging to the network }\end{array}$ \\
\hline Liabilities & Foreignness & Outsidership & Newness \\
\hline
\end{tabular}

\section{METHODOLOGY}

The present study is of the longitudinal retrospective type, i.e., the researcher, situated in a certain moment in time, seeks data that deal with a period in the past, in which the process he or she wishes to examine unfolded (Blazewsky, 2011). Process and time are the central axes for the theoretical development of research. To be consistent with the purposes of the study, we used the case study method of investigation. This choice was justified by the nature of the research question (Ghauri, 2004; Van de Ven \& Huber, 1990); by the fact that the topic is in the early stages of development, with key variables and their relationships being explored (Ghauri, 2004); and, lastly, by the fact that it enables different events to be evaluated over time (Jones \& Khanna, 2006; Welch \& Paavilainen-Mantymaki, 2014).

A single case study was conducted involving the NGO Médecins Sans Frontières - MSF (Doctors Without Borders). A single case study is suitable for exploratory studies that serve as an exploratory stage for future research (Ghauri, 2004), and is appropriate when seeking specific conceptual development (Fletcher \& Plakoyiannaki, 2011), enabling specific issues to be more deeply analyzed from a historical perspective (Bizzi \& Langley, 2012). The following criteria were established for selecting the case to be studied: (a) the NGO must be internationally relevant; (b) it must be active in several countries; and (c) secondary data must be available. MSF was selected because it is one of the largest INGOs. In addition, MSF raises funds from different sources and recruits volunteers in advanced and emerging economies, and employs these resources to support its emergency assistance activities in response to humanitarian crises in other (typically lessdeveloped) countries. Lastly, there is wide availability of freely accessible data on MSF.

The secondary data we used included those available online on MSF's own website (in particular, management and financial reports and meeting minutes), and books, theses, and articles on MSF. The organization's own interviews of active leaders and participants over time, made available in

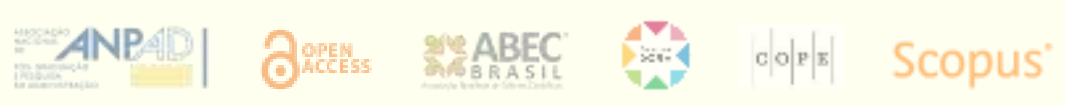


the report by Binet and Saulnier (2017), were one of the most valuable data sources for this study. Secondary data made it possible to retrieve historical data that would have been difficult to obtain otherwise. The various sources made it possible to triangulate the data.

For the data analysis, we drew up an initial report containing a detailed description of the case. Then we proceeded with the analysis based on categories identified in the literature (within-case analysis). In the final stage of the analysis, we compared the results with the categories previously identified in the literature (pattern-matching analysis) related to the internationalization process models (Ghauri, 2004; Pauwels \& Matthyssens, 2004). Next, in light of the two theoretical perspectives adopted in the study, we present the stages of MSF's resource-seeking internationalization to gain access to donors' funds and attract volunteers, and we develop a framework of MSF's resource-seeking internationalization process.

\section{THE NGO MÉDECINS SANS FRONTIÈRES}

MSF aims at providing "medical assistance to people affected by conflict, epidemics, disasters, or exclusion from healthcare." The organization defines itself as a private, international, "non-profit, self-governed, member-based organization” (Médecins Sans Frontières [MSF], 2020). In 2020, MSF served 74 countries with emergency projects and had over 67,000 team members from around 150 countries. Over 95\% of all the funds raised by MSF (1.63 billion euros in 2019) came from private donations, which altogether mobilized 6.5 million individual donors and private organizations (foundations and corporations). MSF employed these funds to fulfill its social mission $(81 \%)$, and to support activities (14\% for fundraising and 5\% for administrative expenses) (MSF, 2020).

MSF is a decentralized organization (Aldashev \& Verdier, 2009). MSF International is the leading association, whose mission is to "safeguard the identity of the MSF movement" (MSF, 2020). MSF International has a board of directors and a president, elected by a general assembly of representatives of 25 independent associations.

Each association also has a board of directors and a president elected by a general assembly. Worldwide activities are coordinated by five operational centers (Belgium, France, Netherlands, Spain, and Switzerland). In addition, $21 \mathrm{MSF}$ sections, each linked to an association, are responsible for recruitment, fundraising, and communication. Some sections have branch offices, and satellite offices are also established to support field work concerning medical, supply, and logistics-related issues (MSF, 2020).

\section{THE INTERNATIONALIZATION OF MSF}

MSF was founded in 1971, in France, by a group of doctors and journalists to provide social and medical assistance to civilians in disaster contexts. The founding group's original motivation was to provide care to victims of the civil war in Biafra, Nigeria. MSF was created as a private nonprofit association, based on the principles of providing humanitarian assistance regardless of race, creed, or ideology; neutrality regarding the internal affairs of governments; confidentiality; and rejection 
of seeking recognition or personal compensation (MSF, 2020). For Binet and Salunier (2017), MSF originated within a favorable context with regard to human resources and markets since there was a contingent of health professionals in France who did not wish to limit their medical skills to their regular practice in a developed country, but wanted to contribute in developing countries. During its first years of existence, MSF did not raise funds or receive financial support; instead, it worked with larger and more experienced NGOs. In 1977, MSF began a process of national expansion, with the decision to create regional sections in France itself to attract local professionals. This led to greater efficiency in terms of recruitment and selection of members, and agility in the flow of information.

The first attempt at internationalization in 1979 consisted of opening a section in the United States, but was unsuccessful. The initiative was based on a proposal by an American physician, who had had no previous contact or experience with MSF, neither had ever participated in the type of activities MSF was engaged. The internationalization plan for the US was aborted due to disagreements among board members. As a result of the experience, an Internationalization Commission was created, which was responsible for analyzing proposals for the international expansion of MSF. In the early 1980s, MSF invested in improving its operational structure to allow for continued growth. At the same time, strategic decisions began to be centralized at the Paris office in order to have greater control over initiatives abroad and compliance with the organization's ethical, political, financial, and legal principles.

In that same year, the process of opening an office in Belgium began, but initially that movement also failed, given that the initiative was handed over to a doctor who had no experience in humanitarian missions. It took a year to assemble a group that was aligned with the spirit of MSF. The new section was linked to the head office by the brand and had financial and operational autonomy. In July 1981, MSF began establishing a subsidiary in Switzerland under French control, but the unit only became a section in 1985-1986, when it acquired a certain amount of autonomy at the initiative of the Swiss individuals involved. According to Binet and Saulnier (2017), the home office continued to view international sections only as peripheral structures that orbited around MSF France, and their fundamental purpose was to provide financial and human resources.

In 1984, a group of Dutch individuals, who had worked with the MSF Belgium team in Chad, requested the opening of an MSF section in the Netherlands. The opening of the section was done autonomously and without the immediate recognition of MSF France, which eventually accepted the proposal, however. That same year, MSF founded the NGO Liberté Sans Frontières (LSF) to study the economic, political, and social situations in underdeveloped countries in order to inform French society about human rights and possible ways for social development in the Third World. However, this branch of MSF generated several internal conflicts due to its political nature, which in 1985 resulted in a temporary rupture between MSF Belgium and MSF France. The disruption was also caused by autonomous actions by MSF Belgium (Aldashev \& Verdier, 2009) that were perceived by MSF France as having endangered MSF teams. Ties between the two units were not restored until 1989 (Binet \& Saulnier, 2017).

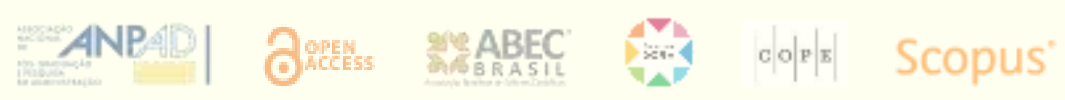


In 1986, MSF opened a section in Luxembourg. The internationalization movement into yet another Benelux country had a clear objective on the part of the Belgians - create an office entailing the Belgian, Dutch, and Luxembourg sections. MSF Luxembourg initially worked under the umbrella of MSF Belgium, receiving financial resources and guidance. This was followed by the creation of MSF Spain in the same year, led by a Spanish doctor who had contacted the head office. MSF France opposed the founding of a new section, but MSF Belgium, MSF Switzerland, and MSF Netherlands gave their support (Binet \& Saulnier, 2017).

Due to previous experience, all sections agreed to suspend the creation of any further MSF sections for a period of three years (from 1987 to 1990). The integration between the sections in search of greater efficiency during missions resulted in the formation of the International Council in 1988, with the objective of improving the international coordination of MSF activities. The International Council was based in Brussels and MSF Belgium became responsible for presiding over the body. In addition, in 1989, one of the doctors associated with the International Council requested the opening of a section in Portugal, under French supervision. In 1990, MSF International was created, with a board composed of members of the International Council. At that time, criteria related to the decision-making process of MSF's internationalization were approved (Binet \& Saulnier, 2017).

In 1991, the Belgian, French, and Dutch sections organized to set up delegations in countries outside Europe with the primary aim of proactively raising funds. Wealthy countries were chosen where public opinion showed a favorable predisposition toward MSF. MSF France was responsible for expanding its activities into the US and MSF Netherlands into Canada. Norway, Sweden, Finland, and Italy were the responsibility of MSF Belgium. Japan was jointly divided between MSF France and MSF Netherlands (Binet \& Saulnier, 2017).

The move into the US came in 1987, nine years after the first (unsuccessful) attempt to open an MSF section there. A nonprofit organization was created, with the board composed entirely of French members. In 1990, it was Greece's turn; in 1991, that of MSF United Kingdom; in 1992, MSF Canada and MSF Japan; in 1993, MSF Sweden, MSF Denmark, and MSF Italy; in 1994, MSF Hong Kong and MSF Australia, and so on.

\section{HOW DID MSF INTERNATIONALIZE?}

We discuss now the convergence, or not, of the internationalization of an NGO with two theoretical perspectives that seek to explain the internationalization process of the firm, and not that of nonprofit organizations. Table 2 summarizes the findings of the study using the categories extracted from the literature. One category - establishment chain - was not found in the study. 
Table 2

\section{The NGO resource-seeking internationalization path}

\begin{tabular}{|c|c|c|c|}
\hline Category & $\begin{array}{l}\text { Pre-internationalization } \\
(1971-1979)\end{array}$ & $\begin{array}{c}\text { Gradual } \\
\text { Internationalization (1980-1990) }\end{array}$ & $\begin{array}{l}\text { Planned Internationalization } \\
\text { (1990 onwards) }\end{array}$ \\
\hline $\begin{array}{l}\text { Locus of the } \\
\text { decision }\end{array}$ & Cause (humanitarian crisis in Biafra) & Network (RUM and BG) & Market and network (BG) \\
\hline Trigger(s) & $\begin{array}{l}\text { Proactive in serving humanitarian } \\
\text { causes (BG); passive in engaging } \\
\text { foreign resources (spontaneous } \\
\text { requests) (OUM) }\end{array}$ & $\begin{array}{l}\text { Generally passive (OUM); network generates opportunities } \\
\text { of foreign expansion (RUM) }\end{array}$ & Proactive in most regards (BG) \\
\hline Uncertainty & $\begin{array}{l}\text { Lack of knowledge of foreign countries } \\
\text { (OUM) }\end{array}$ & $\begin{array}{l}\text { Network members that show interest, shared values, and } \\
\text { commitment reduce uncertainty (RUM) }\end{array}$ & $\begin{array}{l}\text { Uncertainty becomes less relevant; reduced by active search of } \\
\text { trustworthy members who can contribute to organizational goals } \\
\text { (RUM) }\end{array}$ \\
\hline Risk profile & Risk averse (OUM) & Risk averse (OUM) & Risk neutral (BG) \\
\hline Learning & Experiential (OUM) & $\begin{array}{l}\text { Experiential (from the field) and collective (through 'joint } \\
\text { missions, personnel exchanges, information exchanges, } \\
\text { and joint activities') (RUM) }\end{array}$ & $\begin{array}{l}\text { Experiential and collective (RUM); from the network and from } \\
\text { strategic alliances (BG) }\end{array}$ \\
\hline Commitment & To the causes served by MSF & $\begin{array}{l}\text { To the network: to 'the general framework of MSF's } \\
\text { actions' }\end{array}$ & To internationalization; investment of resources (OUM) \\
\hline Psychic distance & Irrelevant at this point & $\begin{array}{l}\text { Preference for opening offices in nearby and similar } \\
\text { countries (exception: Switzerland) (OUM) }\end{array}$ & $\begin{array}{l}\text { Irrelevant; countries are chosen based on their potential to gather } \\
\text { resources to serve MSF's cause ("rich countries, or countries with } \\
\text { an open-minded public opinion") (BG) }\end{array}$ \\
\hline $\begin{array}{l}\text { Establishment } \\
\text { chain }\end{array}$ & Not observed & Not observed & Not observed; diversity of entry modes (BG) \\
\hline Trust & $\begin{array}{l}\text { Appears in the first (failed) attempt to } \\
\text { establish a branch in the US }\end{array}$ & $\begin{array}{l}\text { Considered essential; solid expansion should be based on } \\
\text { 'trustworthy people' (RUM and BG) }\end{array}$ & Still important but not as crucial as in the second stage \\
\hline Liabilities & Irrelevant at this point & Irrelevant at this point & Liabilities of foreignness and outsidership (RUM) \\
\hline Engine of growth & Commitment to humanitarian causes & Entrepreneurial actions of members (BG) & Investments in internationalization (OUM) \\
\hline
\end{tabular}

Note. OUM = Original 1977 Uppsala model; RUM = Revisited 2009 Uppsala model; BG = Born global perspective 
We have added an emerging category to the original set, 'engine of growth,' which was identified as we analyzed the materials. It refers to the driving force behind internationalization.

\section{Pre-internationalization (1971-1979)}

MSF was born with the international purpose of providing humanitarian aid to victims of the civil war in Biafra, thus it can be considered a born global organization. During its preinternationalization stage, the members of the organization displayed a proactive attitude resembling the entrepreneurial characteristics of business leaders described by BG researchers (Hagen \& Zucchella, 2014; Knight \& Liesch, 2016). The beginning of the internationalization process, marked by the foundation of the NGO to serve a specific humanitarian crisis, was not the result of fortuitous events, such as unexpected requests from abroad (as predicted by the 1977 Uppsala model), but was due to the willingness of the organization's members to work abroad, initially with a view to carrying out humanitarian missions, and only afterward to pursue fundraising and attract volunteers, as one of MSF's founders pointed out:

\footnotetext{
“[Internationalization] is not a power-hungry quest for growth, but a desire to carry out MSF's basic mission. Until now, our members have all been French, along with a few foreigners who came to Paris because they needed a structure and technical resources. ... But as the MSF spirit and ethic developed, things in the field changed quickly. ... The internationalisation of MSF is even more important than increasing the number of missions and the money raised. If you think about our most difficult missions, you realise that doctors could have come from countries close by, they would have had a better command of the languages and be better adapted to local conditions. That's how we did things in Latin America (Bernard Kouchner, co-founder of MSF, 1974; transcripts of interview from Binet \& Saulnier, 2017, p. $37)^{\prime \prime}$.
}

Even so, there was no internationalization plan, nor was there a structure for international expansion; quite the contrary, expansion occurred as the means presented themselves:

\footnotetext{
"Back then, there was no organisational vision whatsoever. For us, 'international' meant 'Third World,' in the language of the day, the geopolitics of conflicts. Nobody was thinking about giving MSF an international structure. When we met Dutch people, or others, we'd say that if they wanted to do something for MSF, they could (Claude Malhuret, MSF President, 1978-1979; Member of the Steering Committee, 1979-1985; transcripts of interview from Binet \& Saulnier, 2017, p. 39)”.
}

Although MSF's pre-internationalization stage was similar to that described by the BG perspective, gradualism was already present. As was the case with the Swedish organizations that inspired the original Uppsala model, MSF's entry into foreign countries was preceded by the expansion of its activities from the local ambit (Paris) to the national (all of France). Moreover, MSF's president at the time felt that the organization's resources should be used to improve its structure and to support already-opened French regional units before pursuing internationalization, as exemplified by the failed attempt to open a section in the USA:

"Mr. Goldstein went ahead and established a MSF-USA section. He didn't provide the draft statutes or a list of its Secretariat members, but simply sent a telegram informing us that registration had been filed in the US. The president of MSF considers this a serious breach of confidence. He does not support rushing 
into international expansion when regionalisation still raises many problems (MSF General Assembly Minutes of November 1978, p. 4-5)”.

\section{Gradual resource-seeking internationalization (1980-1990)}

The first steps of MSF's internationalization process were aimed mainly at obtaining financial and human resources. The organization's insertion into the international market occurred in gradual steps marked by an experiential learning process as proposed by the original Uppsala model. Guided by caution, the leaders waited a few years to continue efforts to open offices abroad. In addition, the early choices of countries in which to install new sections were governed by psychic distance, initially expressing a clear preference for opening offices in 'nearby' countries. From France MSF expanded into Belgium, the bordering country where the same language was spoken, and then into the Netherlands and Luxembourg, which, along with Belgium, form Benelux. The entry into Switzerland was much the same because French is also spoken there, and the country has common borders with France. However, entry into Switzerland was due to interest in the country's banking structure, since at the time the French government restricted the flow of money abroad; consequently, projects found it difficult to receive funds from France during emergencies. In addition, since Spain, which has borders with France, and Portugal, its neighbor, are both Latin and Mediterranean countries, there was a logical sequence of psychic distance. Lastly, there was Greece, which is also European and Mediterranean. As early as 1978, a decision by MSF's Assembly foresaw this movement:

"... if this [internationalization] is to occur, it should start in countries closer to France so that MSF can exercise closer oversight - not in the US, where we all know that anything is possible (Minutes of the MSF General Assembly, November 1978, p. 5; emphasis added)”.

Nevertheless, MSF France showed a concern to guide and control the internationalization process, as exemplified with the creation of MSF Spain:

"[MSF Spain was] the result of a collective decision. I had realized that Spain was inevitable and maybe for the best, a potential MSF country. ... Spain had people who had been in the field, who liked it, who were enterprising and had energy. ... The idea wasn't to ... create sections all over the place, but that MSF become a European body with solid bases in different countries and trustworthy people. ... But this had to be done progressively, and we had to be strict about conditions... (Rony Brauman, president of MSF France, 1982-1994; transcripts of interview from Binet \& Saulnier, 2017, p. 77)”.

During this period of the internationalization process, relationship networks appeared in nearly every initiative for opening a new section. Most processes for opening MSF sections in other countries took place via physicians who had volunteered or had other connections with the organization. MSF Belgium was only implemented when individuals with the MSF 'spirit' came together. The founders of MSF Netherlands had previous relations with the founders of MSF Belgium, and MSF Spain was born from a group that had participated in a humanitarian mission in Chad. Such network contacts, which promoted movements into foreign countries, can be seen as triggers for internationalization (Gabrielsson et al., 2008).

"Setting up a structure for the Benelux countries could open a door to internationalisation. Our friendship with the Dutch team should help overcome difficulties, and make this structure truly

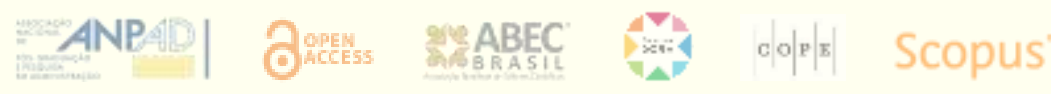


functional and operational. If it works, MSF Benelux would be a model for adding other countries... These special links will increase the efficiency of the collaboration that already exists between Brussels and Amsterdam: joint missions, personnel exchanges, information exchanges, and joint activities (Dr. Eric Goemaere, president of MSF Belgium, 1996-1998; transcripts of interview from Binet \& Saulnier, 2017, p. 72)".

The events that occurred at this stage were related to the characteristics of the entrepreneurial individuals, the organization, and the context, which, together, contributed to forming the value base for MSF's international growth, as suggested by Hagen and Zucchella (2014) in the context of BGs. In fact, the MSF members who headed movements to open sections abroad had characteristics similar to the international entrepreneurs described in the BG literature (Gabrielsson et al., 2008; Rialp, Rialp, \& Knight, 2005): willingness to take on risk, professional experience, and academic competence (Hagen \& Zucchella, 2014; Jones \& Coviello, 2005).

Therefore, the evidence indicates that the psychic distance construct of the original Uppsala model, and the concept of relationship networks included in the revisited Uppsala model and present in the BG literature, are not incompatible, and may act side by side in choosing countries for internationalization, at least in the case of the NGO studied.

\section{Planned internationalization (1990 onwards)}

In 1990, there was a clear rupture in MSF's decision-making process for entry into foreign countries, with the creation of MSF International and the adoption of a planned internationalization strategy, accompanied by improvements in the support infrastructure and a more structured process for investing resources in the opening of international units. This movement aimed mainly at having access to donors and volunteers from other parts of the world. The criteria for choosing countries became different and the initiative moved to MSF itself and was no longer left to others:

\footnotetext{
"The process of starting up delegate offices was nothing like the sudden appearance of a handful of Belgian doctors who travelled with MSF France, and then started MSF Belgium. ... Belgium is a smaller country ..., and fundraising soon dried up. So to find new donors we had to look elsewhere. It was an executive process, not associative. The impetus was that we had to find money, not necessarily have more doctors or nurses from any particular country. We chose rich countries, or countries with an open-minded public opinion that might be favourable to MSF. Then we would start up a section, and collect funds and recruit (Dr. Eric Goemaere, managing director of MSF Belgium, 1996-1998; transcripts of interview from Binet \& Saulnier, 2017, p. 93)”.
}

Only in this new stage did MSF enter psychically distant countries. In Asian countries, psychic distance was mitigated by the existence of network partners that facilitated the process (Guercini $\&$ Runfola, 2011). Entry into Hong Kong showed the existence of relevant cultural differences, although the differences were not perceived to be as striking in the case of Japan, which was becoming more and more westernized and affluent:

"Japan was very much like Europe... Japan was a new model, the leader of the Asian Tigers... Charhon, always the entrepreneur, convinced us we to look at Japan because there was money to be had there (Dr. 
Rony Brauman, president of MSF France, 1982-1994; transcripts of interview from Binet \& Saulnier, 2017, p. 109)".

Networks continued to be implemented to facilitate establishing units abroad. For example, in the case of Denmark, contacting one of the members of the Belgian section in the country brought valuable connections to MSF:

\footnotetext{
"First of all, I had to find members for the board. And I wanted to have a Danish doctor... I got hold of a very nice old friend who I thought had a good network. He thought it would be very cool to be part of MSF, and agreed to be the chair of the board... So this lady organised a charity in honour of MSF. She knew people from the royal family and she invited the Prince Consort of Denmark and other rich card players, and they would pay to come and play cards, and all the money was given to MSF Denmark (Camilla Bredholt, co-founder and chief of staff of MSF Denmark, 1993-1996; member of the board, 1996-2003; transcripts of interview from Binet \& Saulnier, 2017, p. 124)".
}

Thus, MSF needed to form alliances in order to broaden its scope and way of acting (as proposed by Freeman, Edwards, \& Schroder, 2006). At this stage of internationalization, contacts for prospecting for resources were no longer made exclusively with individuals linked to the medical environment or MSF itself, but with multinational companies, providing new forms of learning to the organization (Weerwaderna et al., 2007):

"So I visited 55 of the largest Japanese companies to ask them each for one million yen. It worked. Toshiba, Mitsubishi, Bank of Japan - they all paid up (Dominique Leguillier, MSF co-founder, president, and CEO, 1992-2000; transcripts of interview from Binet \& Saulnier, 2017, p. 111)".

Liabilities of foreignness (Johanson \& Vahlne, 2009) were a complicating factor in the internationalization process, mainly due to the lack of knowledge about local legislation, a problem that arose on several occasions, such as the entry into Australia. Liabilities of outsidership had shown up in some situations and usually indicated the need to resort to local partners, as in the case of Germany:

\begin{abstract}
"They needed somebody in the office who could communicate in German, so they asked me if I wanted to be president. That's how I became president of MSF Germany... We tried to incorporate into the association the few Germans already involved in the movement (Ulrike von Pilar, president of MSF Germany, 1995-1997; managing director, 1997-2005; transcripts of interview from Binet \& Saulnier, 2017, p.126)".

"I had many problems getting MSF Australia off the ground. First of all, in order to have an associated structure in Australia that had tax deductibility, the Australian regulations wanted the majority of the board members to be Australian. However, MSF France wanted the majority of the board members to be French. ... it took me about two years to sort that out (Dr. Peter Hakewill, co-founder and managing director of MSF Australia, 1993-1999; transcripts of interview from Binet \& Saulnier, 2017, p. 130)”.
\end{abstract}

\title{
Conceptualizing the process
}

During the first stage - pre-internationalization -, the NGO's trajectory is quite similar to the aspects described in the original Uppsala model. Despite being a born global organization, given that its first humanitarian activities were developed in a foreign country, the organization was

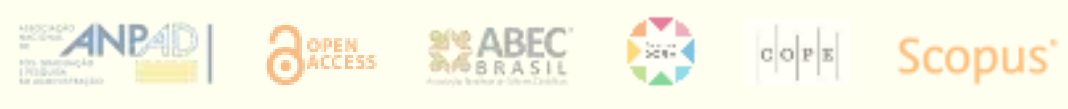


quite reluctant in internationalizing its resource-seeking activities. The period is marked by risk aversion due to the fear of losing control of MSF operations, and by the expansion within the home country, from local to national. The second stage shows a growing interest in internationalization, but still cautious and toward psychically close countries, as predicted by the original Uppsala model. Nevertheless, the role of networks appears in every movement to another country. Entrepreneurial actions by external network members were the driving force toward internationalization. Trust played a crucial role, as well as collective learning. Thus, both versions of the Uppsala model are used to understand this stage of the process. The BG perspective does not have much applicability in this stage, except because it also considers networks.

Finally, the third stage is marked by substantial change in terms of international orientation and proactiveness and the BG perspective is quite useful to understand this stage. Interestingly, this stage starts in the early 1990s, when the forces of globalization were already in motion. At this point, the logic of the NGO internationalization process changes; it becomes proactive and risk neutral. The NGO approaches psychically distant countries and unknown potential partners and makes investments in internationalization. The selection criterion is not trust anymore, but strategic partners capable of donating substantial resources. Although facing liabilities of foreignness and outsidership in some of these new countries, the NGO is well known and respected, and thus able to deal with these liabilities.

Figure 1 shows how each theoretical perspective contributes differently to each of the three stages of the internationalization process. One can see that the Uppsala model (original or revised version) and the BG perspective provide elements that can explain the international trajectory of the NGO during the three stages of the NGO internationalization.

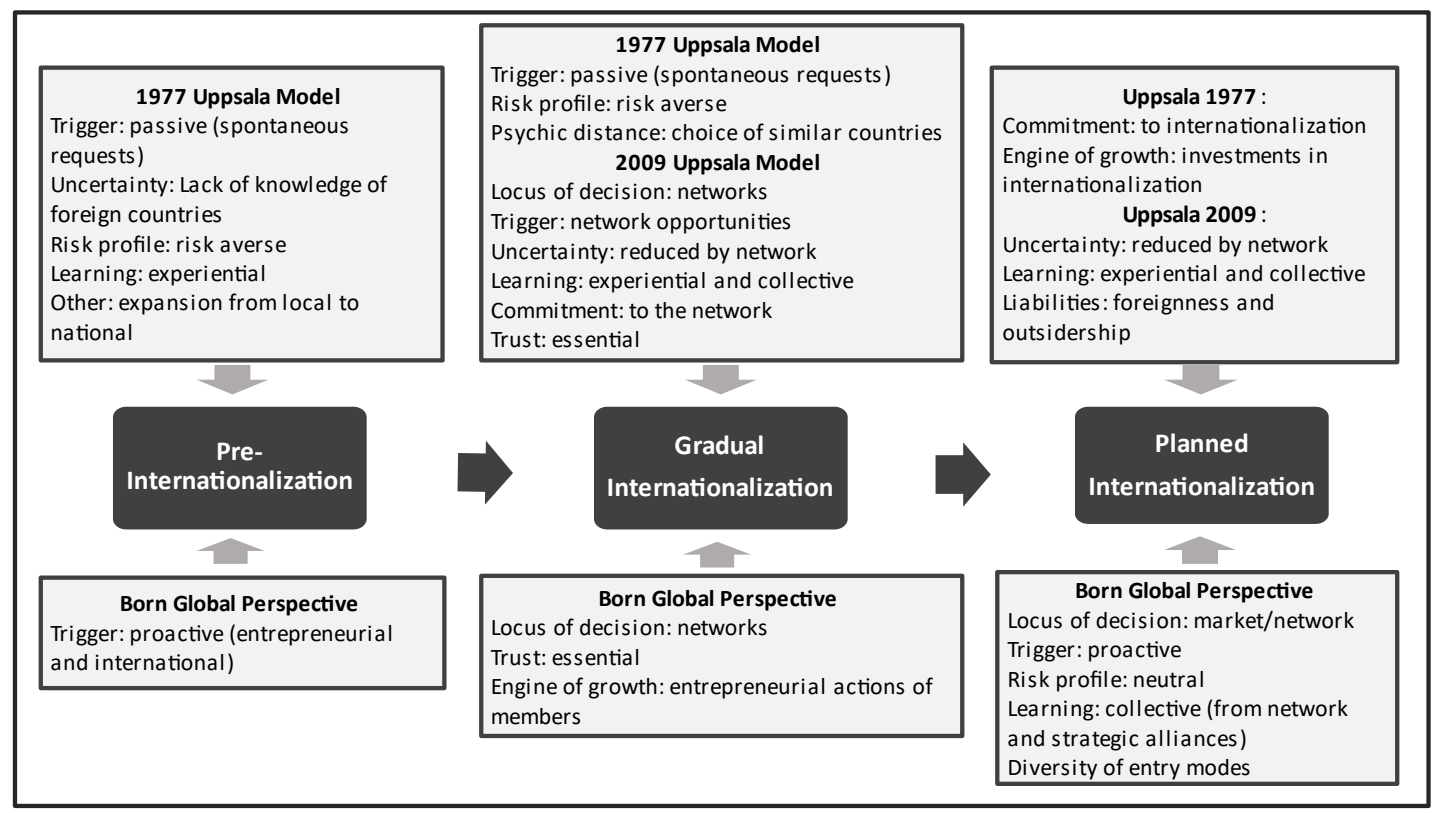

Figure 1. Contributions of the Uppsala model and the BG perspective for understanding the internationalization process of MSF

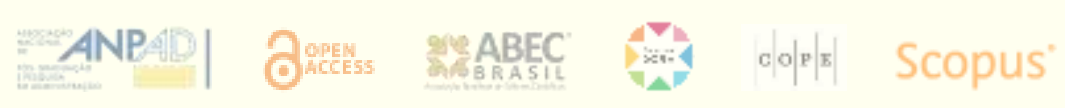




\section{FINAL CONSIDERATIONS}

The results of the study suggest that the theories developed to explain the internationalization process of firms may also be used to analyze the internationalization process of NGOs, at least in their actions aimed at raising human and financial resources. We found that the international trajectory of the NGO Médecins Sans Frontières (MSF) displays similarities to that proposed by two theoretical perspectives, which can be used complementarily to explain this trajectory. However, none of the theoretical perspectives we examined was able, by itself, to explain MSF's international trajectory. Of course, the 1977 and 2009 Uppsala models are not incompatible. On the contrary, the authors themselves emphasize compatibility (Johanson \& Vahlne, 2009), showing that networks are increasingly a central element of internationalization. In turn, the BG perspective also embraces the network theory, which proved equally important for understanding MSF's international trajectory. Although the locus of the present study was an NGO, the countries in which MSF established operational centers and offices constituted markets for obtaining financial and human resources. Consequently, there is an inherent logic in applying internationalization models to organizations with similar characteristics.

Regarding the born global perspective (and its broader insertion in the field of international entrepreneurship), a global orientation is evident from the very start and the entrepreneurial profile of the individuals involved in the process of opening offices and operational centers abroad is in line with a large number of studies in the area (e.g., Chetty \& Campbell-Hunt, 2004; Gabrielsson et al., 2008; Hagen \& Zucchella, 2014). The peculiarity of the NGO is that these entrepreneurs are often members of the organization itself, and may even be simple volunteers, a characteristic that is not observed in the internationalization processes of companies. It is noteworthy that the presence of networks in the process permeates the entire international trajectory of the NGO. It is within the context of the network that opportunities are presented to raise and prospect for resources, and to develop new international branches, allowing the broadening of activities (Gabrielsson \& Kirpalani, 2004).

There are, of course, differences between an NGO and a for-profit organization regarding their internationalization processes. The most important lies on the choice of countries to offering humanitarian aid, which depends on where MSF services are needed, and therefore is not a choice in the same sense used when companies choose markets. In addition, despite the efforts of the French division to keep control over the other MSF sections, the relationship between the sections in different parts of the world and the French founding unit is quite different in terms of structure, power, and control from the typical headquarters-subsidiary relationships.

The Uppsala model's two versions and the born global perspective can be useful for understanding the resource-seeking internationalization process of an $\mathrm{NGO}$; while the first two stages are better explained by the two versions of the Uppsala model, the three theoretical perspectives help understand the final stage. The BG perspective has proved also useful in explaining an NGO's initial internationalization phase starting with entrepreneurial characteristics, but the Uppsala model applies since spontaneous requests from abroad, the expansion from local to national prior to internationalization, and gradualism are all also present.

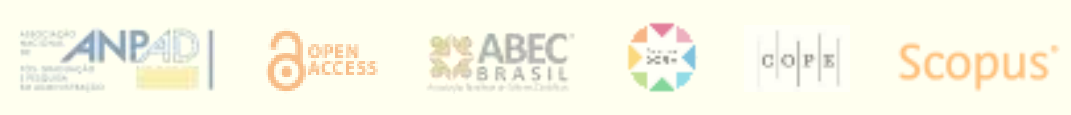


The initial phases in other countries are better explained by the 1977 Uppsala model, since the logic of gradualism resulting from lack of market knowledge (uncertainty), risk aversion, and psychic distance predominates. Then, as the organization progresses, it is the 2009 Uppsala model that seems to better explain the NGO's internationalization process, when psychic distance loses relevance, although the $\mathrm{BG}$ perspective offers a better explanation for proactiveness and risk neutrality in the final phase.

The case study method has limitations regarding the ability to generalize to the population (in this study, international NGOs). Since one can expect to find differences between the NGO studied and other cases of international NGOs, no statistical generalizations can be made. However, one may still resort to theoretical or analytical generalization (Gibbert, Ruigrok, \& Wicki, 2008). Other limitations of the study stemmed from the use of secondary data, which were not originally compiled for the purpose the researchers had in mind. Nevertheless, the fact that the researchers had access to the transcripts of interviews reduced the limitations deriving from the use of secondary data. However, because interviewees refer to past events, it is possible that the data present biases typical of retrospective research.

The present study brings several contributions to the field of IB. First, it shows the applicability of internationalization theories to an NGO's entry activities into markets for obtaining financial and human resources. Second, it shows that the two versions of the Uppsala model may coexist with the born global perspective. In particular, the results show that gradualism can dominate in a born global organization and that psychic distance can coexist with the use of networks regarding decisions to enter new markets. It may not be a peculiarity of an NGO, but it may also occur throughout the international trajectory of for-profit organizations. Third, the study contributes specifically to the literature on INGOs in exploring the issue of raising funds and human resources internationally. Further studies may verify and extend the contributions of the present work.

\section{REFERENCES}

Aldashev, G., \& Verdier, T. (2009). When NGOs go global: Competition on international markets for development donations. Journal of International Economics, 79(2), 198-210. https://doi.org/10.1016/j.jinteco.2009.07.007

Anheier, H. K. \& Themudo, N. (2005). The internationalization of the nonprofit sector (pp. 100-128). In R. D. Herman \& Associates (Eds.), The Jossey-Bass handbook of nonprofit leadership and management. $2^{\text {nd }}$ ed. San Francisco, CA: John Wiley \& Sons.

Banks, N., Hulme, D., \& Edwards, M. (2015). NGOs, states, and donors revisited: Still too close for comfort? World Development, 66, 707-718. https://doi.org/10.1016/j.worlddev.2014.09.028

Bebbington, A. J., Hickey, S., \& Mitlin, D. C. (2008). Introduction: Can NGOs make a difference? The challenge of development alternatives (pp. 3-4). In A. J. Bebbington, S. Hickey, \& D. C. Mitlin (Eds.), Can NGOs make a difference? The challenge of development alternatives. London: Zed Books.

Bhanji, Z., \& Oxley, J. E. (2013). Overcoming the dual liability of foreignness and privateness in international corporate citizenship partnerships. Journal of International Business Studies, 44(4). $290-311$. https://doi.org/10.1057/jibs.2013.8

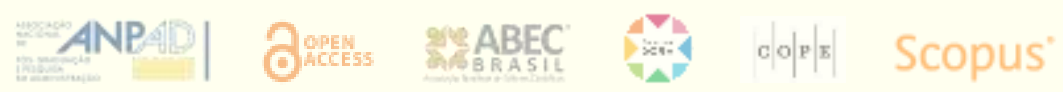


Binet, L., \& Saulnier, M. (2017). Médecins Sans Frontières, evolution of an international movement: Associative history. Retrieved from http://www.msf.org/

Bizzi, L., \& Langley, A. (2012). Studying processes in and around networks. Industrial Marketing management, 41(2), 224-234. https://doi.org/10.1016/j.indmarman.2012.01.007

Björkman, I., \& Forsgren, M. (1997). Nordic contributions to international business research (pp. 11-29). In Björkman, I., \& Forsgren, M. (Eds.), The nature of the international firm: Nordic contributions to international business research. Copenhagen: Munksgaard International.

Blazejewski, S. (2011). When truth is the daughter of time: Longitudinal case studies in international business research (pp. 251-276). In R. Piekkari, \& C. Welch (Eds.), Rethinking the case study in international business and management research. Cheltenham, UK: Edward Elgar Publishing.

Buckley, P. J. (2002). Is the international business research agenda running out of steam? Journal of International Business Studies, 33(2), 365-373. https://doi.org/10.1057/palgrave.jibs.8491021

Buckley, P. J., Doh, J. P., \& Benischke, M. H. (2017). Towards a renaissance in international business research? Big questions, grand challenges, and the future of IB scholarship. Journal of International Business Studies, 48, 10451064. https://doi.org/10.1057/s41267-017-0102-z

Davies, T. (2018). The historical development of NGOs (pp. 15-33). In A. Kellow, \& H. Murphy-Gregory (Eds.), Handbook of research on NGOs. Cheltenham, UK: Edward Elgar.

Denk, N., Kaufmann, L., \& Roesch, J-F. (2012). Liabilities of foreignness revisited: A review of contemporary studies and recommendations for future research. Journal of International Management, 18(4), 322-334. https://doi.org/10.1016/j.intman.2012.07.001

Dichter, T. W. (1999). Globalization and its effects on NGOs: Efflorescence or a blurring of roles and relevance? Nonprofit and Voluntary Sector Quarterly, 28(4), 38-58. https://doi.org/10.1177\%2F089976499773746429

Ebrahim, A. (2003). Accountability In Practice: Mechanisms for NGOs. World Development, 31(5), $813-829$. https://doi.org/10.1016/S0305-750X(03)00014-7.

Edwards, M. (2008). Have NGOs 'made a difference?' From Manchester to Birmingham with an elephant in the room (pp. 9-17). In A. J. Bebbington, S. Hickey, \& D. C. Mitlin (Eds.), Can NGOs make a difference? The challenge of development alternatives. London: Zed Books.

Fletcher, M., \& Plakoyiannaki, E. (2011). Case selection in international business: Key issues and common misconceptions (pp. 171-192). In R. Piekkari \& C. Welch (Eds.), Rethinking the case study in international business and management research. Cheltenham, UK: Edward Elgar Publishing.

Forsgren, M. (2002). The concept of learning in the Uppsala internationalization process model: a critical review. International Business Review, 11(3), 257-277. https://doi.org/10.1016/S0969-5931(01)00060-9

Freeman, S., Edwards, R., \& Schroder, B. (2006). How smaller Born Global firms use networks and alliances to overcome constraints to rapid internationalization. Journal of International Marketing, 14(3), 33-63. https://doi.org/10.1509\%2Fjimk.14.3.33

Gabrielsson, M., Kirpalani, V. H. M., Dimitratos, P., Solberg, C. A., \& Zucchella, A. (2008). Born Global: Propositions to help advance the theory. International Business Review, 17(4), 385-401.

Gabrielsson, M., \& Kirpalani, V. H. M. (2004) Born globals: How to reach new business space rapidly. International Business Review, 13(5), 555-571. https://doi.org/10.1016/j.ibusrev.2004.03.005

Ghauri, P. (2004). Designing and conducting case studies in international business research (pp. 109-124). In R. Piekkari \& C. Welch (Eds.), Handbook of qualitative research methods for international business. Cheltenham, UK: Edward Elgar Publishing.

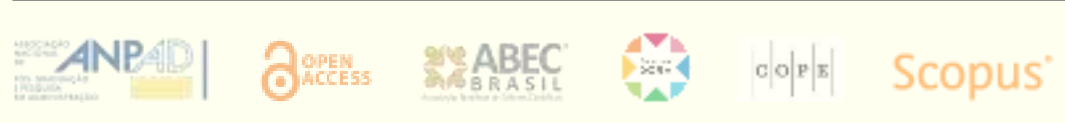


Gibbert, M, Ruigrok, W., \& Wicki, B. (2008). What passes as a rigorous case study? Strategic Management Journal, 29(13), 1465-1474. https://doi.org/10.1002/smj.722

Guercini, S., \& Runfola, A. (2011). Marketing cooperation and public policy in Italian networks of fashion firms (pp. 163-184). In M. Johanson \& H. Lundberg (Eds.), Network strategies for regional growth. Londres; Palgrave Macmillan.

Hagen, B., \& Zucchella, A. (2014). Born global or born to run? The long-term growth of born global firms. Management International Review, 54(4), 497-525. https://doi.org/10.1007/s11575-014-0214-7

Hewerdine, L., \& Welch, C. (2013). Are international new ventures really new? A process study of organizational emergence and internationalization. Journal of World Business, 48(4), 466-477. https://doi.org/10.1016/j.jwb.2012.09.003

Johanson, J., \& Vahlne, J-E. (1977). The internationalization process of the firm-a model of knowledge development and increasing foreign market commitments. Journal of International Business Studies, 8(1), 23-32. https://doi.org/10.1057/palgrave.jibs.8490676

Johanson, J., \& Vahlne, J-E. (1990). The mechanism of internationalisation. International Marketing Review, 7(4), 11 24. https://doi.org/10.1108/02651339010137414

Johanson, J. \& Vahlne, J-E. (2009). The Uppsala internationalization process model revisited: From liability of foreignness to liability of outsidership. Journal of International Business Studies, 40(9), 1411-1431. https://doi.org/10.1057/jibs.2009.24

Jones, G., \& Khanna, T. (2006). Bringing history (back) into international business. Journal of International Business Studies, 37(4), 453-468. https://doi.org/10.1057/palgrave.jibs.8400198

Jones, M. V., \& Coviello, N. E. (2005). Internationalisation: conceptualising an entrepreneurial process of behaviour in time. Journal of International Business Studies, 36(3), 284-303. https://doi.org/10.1057/palgrave.jibs.8400138

Kellow, A., \& Murphy-Gregory, H. (2018) MGOs and global politics (pp. 1-13). In A. Kellow \& H. Murphy-Gregory (Eds.), Handbook of research on NGOs. Cheltenham, UK: Edward Elgar.

Kistruck, G. M., Qureshi, I., \& Beamish, P. (2013). Geographic and product diversification in charitable organizations. Journal of Management, 39(2), 496-530. https://doi.org/10.1177/0149206311398135

Knight, G. A., \& Cavusgil, S. T. (2005). A taxonomy of born-global firms. Management International Review, 45(3), $15-35$.

Knight, G. A., \& Liesch, P. W. (2016). Internationalization: From incremental to born global. Journal of World Business, 51(1), 93-102. https://doi.org/10.1016/j.jwb.2015.08.011.

Kourula, A., \& Laasonen, S. (2010). Nongovernmental organizations in business and society, management, and international business research: Review and implications from 1998 to 2007. Business $\mathcal{E}$ Society, 49(1), 35-67. https://doi.org/10.1177\%2F0007650309345282

Lambell, R., Namia, G., Nyland, C., \& Michelotti, M. (2008). NGOs and international business research: Progress, prospects and problems. International Journal of Management Reviews, 10(1), 75-92. https://doi.org/10.1111/j.1468-2370.2007.00218.x

Lewis, D. (2005). The management of non-governmental development organizations. London: Routledge.

Martens, K. (2002). Mission impossible? Defining nongovernamental organizations. Voluntas: International Journal of Voluntary and Nonprofit Organizations, 13(3), 271-285. https://doi.org/10.1023/A:1020341526691 
McGaughey, F. (2018). From gatekeepers to GONGOs: A taxonomy of Non-Governmental Organisations engaging with United Nations human rights mechanisms. Netherlands Quarterly of Human Rights, 36(2): 111-132. https://doi.org/10.1177\%2F0924051918771232

Meyer, M., \& Simsa, R. (2014). Developments in the Third Sector - the last decade and a cautious view into the future (pp. 203-216). In M. Freise, \& T. Hallmann (Eds.), Modernizing democracy. New-York: Springer. https://doi.org/10.1007/978-1-4939-0485-3_17

Miller, J. (2007). Neither state nor market: NGOs and the international third sector. Global Media and Communications, 3(3), 352-355. https://doi.org/10.1177\%2F17427665070030030503

Medécins sans Frontières (2020). Medécins sans Frontières. Retrieved from https://www.msf.org

United Nations (2017). NGO Branch, Office for ECOSOC Support and Coordination, UN DESA. Retrieved from http://csonet.org/

Nebus, J., \& Rufin, C. (2010). Extending the bargaining power model: Explaining bargaining outcomes among nations, MNEs, and NGOs. Journal of International Business Studies, 41(6), 996-1015. https://doi.org/10.1057/jibs.2009.43

Ninan, S. \& Puck, J. F. (2010). The internationalization of Austrian firms in Central and Eastern Europe. Journal for East European Management Studies, 15(3), 237-259.

Oelberger, C. R., Lecy, J., \& Shachter, S. Y. (2020). Going the extra mile: The liability of foreignness in U.S. foundation international grantmaking to local NGOs. Nonprofit and Voluntary Sector Quarterly, 49(4), 776-802. https://doi.org/10.1177\%2F0899764020901812

Parker, A. R. (2003). Prospects for NGO Collaboration with Multinational enterprises (pp. 82-103). In J Doh, \& H. Teegen (2003). Globalization and NGOs: Transforming business, government and society. Westport, CT: Praeger.

Pauwels, P., \& Matthyssens, P. (2004). The architecture of multiple case study research in international business (pp. 125-143). In R Piekkari, \& C Welch. Handbook of qualitative research methods for international business. Cheltenham, UK: Edward Elgar Publishing.

Rana, M. B., \& Elo, M. (2017). Transnational diaspora and civil society actors driving MNE internationalization: the case of Grameenphone in Bangladesh. Journal of International Management, 23 (1), 87-106. https://doi.org/10.1016/j.intman.2016.11.005

Rialp, A., Rialp, J., \& Knight, G. A. (2005). The phenomenon of early internationalizing firms: what do we know after a decade (1993-2003) of scientific inquiry? International Business Review, 14(2), 147-166. https://doi.org/10.1016/j.ibusrev.2004.04.006

Risse, T. (2007). Transnational actors and world politics (pp. 251-286). In W. C. Zimmerli, K. Richter, \& M. Holzinger (Eds.), Corporate ethics and corporate governance. Berlin: Springer.

Salomon, L. M., \& Anheier, H. K. (1997). Defining the nonprofit sector: a cross-national analysis. Manchester, UK: Manchester University Press.

Sinkovics, N., Sinkovics, R. R. \& Archie-Acheampong J. (2019). An overview of social responsibility dimensions in international business (pp. 29-72. In L. C. Leonidou, C. S. Katsikeas, S. Samiee, \& C. N. Leonidou, (Eds.), Socially responsible international business: Critical issues and the way forward. Cheltenham, U.K.: Edward Elgar Publishing.

Smillie I. (1998). NGOs and development assistance: a change in mind-set? (pp. 184-202) In T. G. Weiss (Eds.), Beyond UN subcontracting. International Political Economy Series. London: Palgrave Macmillan.

Teegen, H., Doh, J. P., \& Vachani, S. (2004). The importance of nongovernmental organizations (NGOs) in global governance and value creation: An international business research agenda. Journal of International Business Studies, 35(6), 463-483. https://doi.org/10.1057/palgrave.jibs.8400112

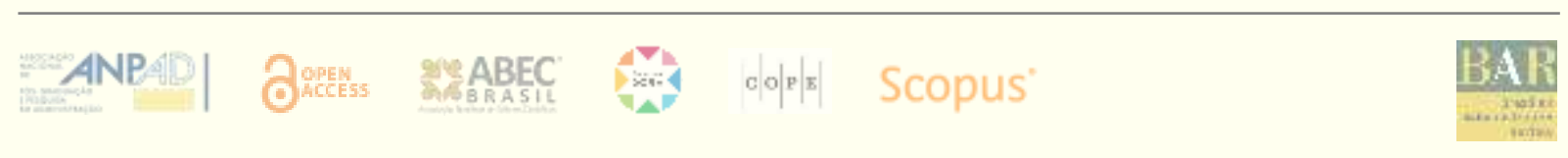


Uphoff, N. (1996). Why NGOs are not a third sector: A sectoral analysis with some thoughts on accountability, sustainability and evaluation (pp. 23-39). In M. Edwards, \& D. Hulme (Eds.), Non-governmental organizations: performance and accountability - Beyond the magic bullet. London: Save the Children.

Vakil, A. C. (1997). Confronting the classification problem: Toward a taxonomy of NGOs. World Development, 25(12), 2057-2070. https://doi.org/10.1016/S0305-750X(97)00098-3

Van De Ven, A. H., \& Huber, G. P. (1990). Longitudinal field research methods for studying processes of organizational change. Organization Science, 1(3), 213-219. https://doi.org/10.1287/orsc.1.3.213

Vissak, T., \& Francioni, B. (2013). Serial nonlinear internationalization in practice: A case study. International Business Review, 22(6), 951-962. https://doi.org/10.1016/j.ibusrev.2013.01.010

Weerawardena, J., Mort, G. S., Liesch, P. W., \& Knight, G. (2007). Conceptualizing accelerated internationalization in the born global firm: A dynamic capabilities perspective. Journal of World Business, 42(3), 294-306. https://doi.org/10.1016/j.jwb.2007.04.004

Welch, C., Nummela, N., \& Liesch, P. (2016). The Internationalization process model revisited: An agenda for future research. Management International Review, 56(6), 783-804. https://doi.org/10.1007/s11575-016-0302-y

Welch, C., \& Paavilainen-Mantymaki, E. (2014). Putting process (back) in: research on the internationalization process of the firm. International Journal of Management Reviews, 16(1), 2-23. https://doi.org/10.1111/ijmr.12006

Werker, E., \& Ahmed, F. Z. (2008). What do nongovernmental organizations do? The Journal of Economic Perspectives, 22(2), 73-92. https://doi.org/10.1257/jep.22.2.73

Yang, A., \& Gabrielsson, P. (2018). The interface of international marketing and entrepreneurship research: review, synthesis and future directions. Journal of International Marketing, 26(4), 18-37. https://doi.org/10.1177\%2F1069031X18809988

Zaheer, S. (1995). Overcoming the liability of foreignness. Academy of Management Journal, 38(2): $341-363$. https://doi.org/10.5465/256683 


\section{Authors' contributions}

$1^{\text {st }}$ author: conceptualization (lead), investigation (lead), methodology (equal), writing - original draft (lead).

$2^{\text {nd }}$ author: conceptualization (supporting), methodology (equal), supervision (lead), writing - review \& editing (lead).

\section{Authors}

\section{Paula Porto*}

Fundação de Apoio à Escola Técnica

Rua Luiz Fernando Carrielo, no. 39, Jd. Ornelas Bom Jardim, 28660-000, Rio de Janeiro, RJ, Brazil paulappontes@gmail.com

(D) https://orcid.org/0000-0002-9645-4407

\section{Angela da Rocha}

Pontifícia Universidade Católica do Rio de Janeiro, IAG - Escola de Negócios

R. Marquês de São Vicente, no. 225, Gávea, 22541-041, Rio de Janeiro, RJ, Brazil angelarocha@iag.puc-rio.br

(D) https://orcid.org/0000-0001-6651-0933

* Corresponding author

Peer review is responsible for acknowledging an article's potential contribution to the frontiers of scholarly knowledge on business or public administration. The authors are the ultimate responsible for the consistency of the theoretical references, the accurate report of empirical data, the personal perspectives, and the use of copyrighted material.

This content was evaluated using the double-blind peer review process. The disclosure of the reviewers' information on the first page is made only after concluding the evaluation process, and with the voluntary consent of the respective reviewers. 